\begin{tabular}{l|l} 
Variants & $\begin{array}{l}\text { Variants } \\
\text { The Journal of the European Society for Textual } \\
\text { Scholarship }\end{array}$
\end{tabular}

12-13 | 2016

Varia

\title{
Joachim Maria Machado de Assis, Dom Casmurro
}

\section{Jessica Firmino}

\section{OpenEdition}

\section{Journals}

\section{Electronic version}

URL: http://journals.openedition.org/variants/393

DOI: $10.4000 /$ variants.393

ISSN: 1879-6095

\section{Publisher}

European Society for Textual Scholarship

\section{Printed version}

Date of publication: 31 December 2016

Number of pages: 255-257

ISSN: 1573-3084

\section{Electronic reference}

Jessica Firmino, « Joachim Maria Machado de Assis, Dom Casmurro », Variants [Online], 12-13| 2016, Online since 01 May 2017, connection on 25 September 2020. URL : http://journals.openedition.org/ variants/393 ; DOI : https://doi.org/10.4000/variants.393

This text was automatically generated on 25 September 2020.

The authors 


\title{
Joachim Maria Machado de Assis, Dom Casmurro
}

\author{
Jessica Firmino
}

\section{REFERENCES}

Joachim Maria Machado de Assis. Dom Casmurro. Ed. Maximiano de Carvalho e Silva: Niterói: Editora da UFF/FAPERJ, 2014. 480 pp. ISBN 978-85-228-0967-7.

1 The critical edition of the writings of Machado de Assis (1839-1908) began in the late 1950s when the work of this Brazilian writer fell in the public domain. The uncertain reliability of Machado's texts published until 1958 was at the origin of the decision of the then President of Brazil, Kubitschek de Oliveira, to recommend the creation of a Committee responsible for the critical establishment of his oeuvre and, afterwards, of the works of other authors deserving of similar treatment.

2 The novel Dom Casmurro - a masterpiece in the view of many - stages, as K. David Jackson puts it in an article in the New York Times, "a retrospective memoir" written from the main character's point of view "for the single self-serving purpose of proving, or justifying, an obsessive belief. He is certain that the beautiful Capitu [...] had betrayed him with their best friend, Escobar, the real father of their son Ezequiel" (22 February 1998). The critical edition of this beautifully built novel was first published in 1966 (reprinted in 1968 and 1975). Now, almost 50 years after the original publication, Maximiano de Carvalho e Silva has produced a revised, updated and expanded edition. A collaborator of Celso Cunha, the general editor of the Machado de Assis edition, Carvalho e Siva had been responsible for the collation and textual analysis of the 1966 edition.

3 Although there was a later printing issued during Machado's lifetime, the base text of this critical edition is still the one which was published in 1899, the last one known to have been revised by the author. This choice is supported by the identification and correction of seemingly textual errors, which were divided into two groups. The first 
contains the errors of the 1899 edition (siglum A), including those shared with the first unrevised printing (siglum B); the second contains only the exclusive errors of the latter. The reading text is presented without editorial interruptions apart from the use of asterisks and paragraph numbering which allow cross-referencing to the critical annotation placed at the end of the text. Although not many errors were present in the base text, leaving the reading text largely unencumbered with editorial marks was a deliberate strategy to reconcile the needs of textual scholars with those of general readers.

4 The critical text is preceded by a note introducing the Editorial Committee and what may be called the Rio de Janeiro philological school. This is followed by a brief criticalphilological introduction extracted from the 1966 edition that sets out the editorial rationale and the foreword to the 1975 edition (a single page that sets out the changes with the previous edition). This in turn is followed by a new section providing information about the texts that have been collated, the editorial interventions and the textual organization. Following the critical text there is a transcription (and proposed correction) of suspected textual errors, which was published in 1896 as "Um Agregado" in the newspaper República and used for the writing of some chapters of Dom Casmurro. The transcription is accompanied by a comparative analysis of this text with the corresponding passages in Machado's novel. Then comes the critical apparatus containing all the identified textual errors and the scholarly annotations (including matters of transcription and allusions to other authors not included in the previous edition), as well as a number of tables dealing with orthography and linguistic traits unique to the author's style. The volume closes with a substantial essay on the life and work of Machado de Assis, covering the historical-cultural context and some early reviews of Dom Casmurro.

5 Although this is not a new edition of Dom Casmurro, it is an important piece of scholarship. Textual errors that were overlook in the 1966 edition are corrected here and documented separately in the apparatus. Not only this, the care Carvalho e Silva has taken in explaining the lapses in his earlier work is certainly commendable.

\section{AUTHORS}

\section{JESSICA FIRMINO}

Jessica Firmino received a BA in Literature and Linguistics from the University of São Paulo (Brazil) and an MA in Textual Criticism from the University of Lisbon. She has mainly worked in the fields of Portuguese Language and of Portuguese Linguistics. She is a member of the Centre for Linguistics of the University of Lisbon, where she is editing texts by the Portuguese 19thcentury novelist Camilo Castelo Branco. 